\title{
Luxury limbo: temporal techniques of border control and the humanitarianisation of waiting
}

\author{
Anne McNevin* \\ The New School, \\ 79 5th Ave, New York 10003, USA \\ Email: mcnevina@newschool.edu \\ *Corresponding author
}

\author{
Antje Missbach \\ School of Social Sciences, \\ Monash University, Australia \\ Email: antje.missbach@monash.edu
}

\begin{abstract}
In this article, we examine temporal techniques of border control including prolonged periods of waiting, stasis and indeterminacy that increasingly characterise the experience of refugees, asylum seekers and other irregular migrants. We argue that these temporal techniques are enhanced and legitimised by parallel efforts to improve accommodation for irregular migrants - a process we call the humanitarianisation of waiting. We focus on the Indonesian context, where growing numbers of refugees wait for resettlement elsewhere, whilst housed in non-custodial alternatives to detention. We show how the promotion of alternatives to detention as humane and pragmatic enables containment strategies pursued through migration management to persist under a cloak of benevolence. The result is a kind of 'luxury' limbo that refugees experience and through which it becomes harder to disentangle the managerial emphasis on migrant care from the more pernicious practices of border security. The paper's analytical distinction between spatial and temporal techniques of border control illuminates the vexed politics of humanitarianism with respect to human mobility in the Indonesian context and beyond.
\end{abstract}

Keywords: alternatives to detention; borders; refugees; humanitarianism; temporality; Indonesia; migration management; waiting; irregular migration.

Reference to this paper should be made as follows: McNevin, A. and Missbach, A. (2018) 'Luxury limbo: temporal techniques of border control and the humanitarianisation of waiting', Int. J. Migration and Border Studies, Vol. 4, Nos. 1/2, pp.12-34.

Biographical notes: Anne McNevin is an Associate Professor of Politics at the New School for Social Research. She is the author of Contesting Citizenship: Irregular Migrants and New Frontiers of the Political (Columbia University Press, 2011) and an Associate Editor of Citizenship Studies.

Antje Missbach is a Senior Lecturer in Anthropology and Research Fellow in the School of Social Sciences, Monash University. She is the author of Troubled Transit: Asylum Seekers Stuck in Indonesia, (ISEAS: 2015) and Politics and Conflict in Indonesia: The Role of the Acehnese Diaspora (Routledge: 2011). 


\section{Introduction}

"Inflicting torture by the use of time is the best and complete explanation of this situation."

Behrouz Bouchani (2016)

Kurdish journalist from Iran and asylum seeker, describing 28 months in 'offshore' detention on Papua New Guinea's Manus Island.

Border control is usually thought of in spatial terms, incorporating the demarcation and policing of territories to enable or restrict entry and exit, as well as the spatial containment and confinement of irregular migrants - asylum seekers and refugees amongst them. In this article we focus, by contrast, on temporal techniques of border control with specific regard to refugees who are stuck in Indonesia for extended periods of time. The Indonesian case speaks to more general experiences of waiting, deferral and uncertainty to which irregular migrants are subject. We examine these experiences in relation to the broader exercise of migration management, the international policy orthodoxy promoted by the International Organization for Migration (IOM), amongst other inter-governmental organisations. The task of migration management is to organise human mobility in an orderly, economically productive, and humane fashion in line with state security interests, prevailing growth and development objectives, and human rights norms (IOM, 2005). Migration management encompasses attention to the human rights of refugees and asylum seekers, even though many states pursuing this agenda, including Indonesia, are not signatories to the International Refugee Convention.

In conversation with literature that is critical of migration management from a governmentality perspective (see Geiger and Pécoud, 2013), this article builds on work that has documented the hardships associated with prolonged status determination procedures and the lack of 'durable solutions' for asylum seekers and refugees in Indonesia who frequently confront either destitution or appalling conditions in immigration detention (Taylor, 2009; Taylor and Rafferty-Brown, 2010; Missbach, 2015). In order to pursue a sharper focus on the temporal dimension, however, our research is based on the experience of refugees who reside in what are arguably model examples of non-custodial accommodation known as alternatives to detention. We describe in detail the temporal experience of refugees waiting in a 'best practice' example of such alternatives: the Sidoarjo centre in East Java. Our analysis shows how efforts to improve the spatial dimensions of border control (that is, the space of confinement itself) enables the more systematic application of temporal techniques of control (prolonged indeterminacy). We call this process the humanitarianisation of waiting. The humanitarianisation of waiting makes it harder to disentangle the managerial exercise of migrant care from the more pernicious practices of border security. In light of this effect, our use of the term 'luxury' to describe the material conditions in which refugees wait is deliberately tongue-in-cheek. Even in the best case examples, the accommodation we describe is far from luxurious. We use the term 'luxury' in this exaggerated way in order to make the point that no amount of 'luxury', genuine or otherwise, can alter the effects of temporal confinement.

Our argument aligns with the work of scholars who have shown in the UK and elsewhere that attempts to humanise accommodation and waiting times for asylum seekers legitimise and depoliticise confinement and waiting itself (Bagelman, 2016; Gill, 2016; Tyler et al., 2014; Morris, 2016). Where those accounts have emphasised the ways 
in which compassion (Gill, 2016) or hope (Bagelman, 2016) have been mobilised with this system-serving result, we show how appeals to efficiency and pragmatism in the alternatives to detention model deliver a similar effect. We acknowledge the market dynamics that contribute to the design and delivery of alternatives to detention, however, we do not maintain as Morris (2017) does, that efforts to improve accommodation for irregular migrants can be reduced to economic interests alone. Rather, those efforts are better understood in light of what Squire (2015, p.40) calls a contested 'humanitarian politics'. We theorise the humanitarian politics of waiting in Indonesia and beyond, drawing on the work of Ghassan Hage. We show how the terms and conditions in which people wait are grossly unequal and play into circular rationales for containment and deterrence.

The article draws on extensive periods of fieldwork and ethnographic inquiry into the experience of asylum seekers and refugees in Indonesia between 2010 and 2016 . We draw more specifically on time spent visiting Indonesian immigration detention centres and various forms of accommodation for asylum seekers and refugees over three separate month-long field trips to Indonesia in 2014, 2015 and 2016. During this time, we interviewed or spoke informally with asylum seekers and refugees, officials of relevant government departments and staff of relevant NGOs and intergovernmental agencies involved in the provision of detention, accommodation and care for asylum seekers and refugees.

We place refugees at the centre of our analysis by documenting daily routines and experiences of time within relatively 'luxurious' spaces of confinement. These accounts appear as stand-alone vignettes throughout the paper. Our purpose here is twofold. First, in keeping with the temporal emphasis taken in the article, we attempt to capture something of the rhythms that make up the everyday for refugees in Indonesia. Often, this involves an absence of meaningful activity: a generic and monotonous quality that fills long periods of waiting for a future to come. This is the limbo we refer to in our title. Second, mindful of the 'moral distancing' that results from dispassionate and depersonalised accounts of refugee experience [Gill, (2016), p.6], we attempt to offer a more grounded engagement with the everyday effects of migration management on refugees. In order to do so, we mimic the approach of Cabrera (2013), who places lists of the discarded belongings of migrants crossing the USA-Mexico border throughout a more abstract discussion of global social justice. Cabrera (2013, p.2) argues that:
"[the documentation of s]uch material [belongings] can help to make the lives of excluded others more vivid, their interests and plain humanity more present in the theoretical frame. It can challenge common-sense understandings about the depth of duties to non-compatriot others, and perhaps most importantly, it can help to make more difficult the blithe dismissal of their claims, or the theoretical treatment of their concerns or deprivations as self-evidently less pressing that those of individuals who are perceived as closer in geographical or relational terms."

The 'plain humanity' to which Cabrera (2013) refers has been subject to extensive critique by scholars who show how generalised notions of humanity mask longstanding hierarchies and exclusions (Barnett, 2011; Fassin, 2012; Squire, 2015). Whatever intuitive associations are evoked by the term 'plain humanity', they bear little resemblance to the increasingly technical operationalisation of humanitarian discourse as part of migration management. For well over a decade, scholars have theorised the instrumentalisation of humanitarian sentiment within the global governance of migration 
(Harrell-Bond, 1999; Chimni, 2000; Ticktin, 2011; Walters, 2011). As a result, the faith once placed in humanitarianism as an obvious point of contrast with punitive, hierarchical and violent aspects of border control has been powerfully challenged. Against this background, we attempt to illuminate the disjuncture between personal and managerial accounts of human experience, in part by adapting Cabrera's (2013) approach. Rather than belongings in space, we present snapshots in time. These snapshots of refugees' experiences sit separately to the body of the article in an awkward reflection of the separation between that part of humanity that travels the world with ease and speed and that part whose mobility is stalled, circumscribed and policed. For as much as we may wish to let the latter part count as fully and equally human by portraying something of their 'plain humanity' via these vignettes, the temporal confinement we highlight in this article suggests that 'plain humanity' is not enough to make some count as much as others.

Said is a 31-year-old man and former goods trader from Iran. He arrived in Indonesia in June 2013. He was caught by immigration authorities in Sulawesi where he was waiting in the jungle for a boat to be smuggled to Australia. He was detained in a hotel room for five months and then in Bangil Immigration Detention Centre for ten months. He received his refugee status whilst in detention but it was three months later before he was released. He has lived in the Sidoarjo refugee accommodation centre since then.

A.M: How do you spend your time?

S: I sleep in the morning, I drink tea, watch movies.

\section{Temporal techniques of border control}

There is now a substantial literature that addresses the intersection of spatiality, temporality and border regimes (Cwerner, 2004; Anderson et al., 2009; Gill, 2009; Mezzadra and Neilson, 2013; Brendese, 2013; Anderson and Keith, 2014; Griffiths, 2014; Little, 2015; Bagelman, 2016; Jeffrey, 2008; Conlon, 2011; Hasselberg, 2016; Martin, 2011). This literature points to specific examples and generalised patterns "where the compression, elongation and partitioning of time exerts effects of control, filtering and selectivity" upon human mobility [Mezzadra and Nielson, (2013), p.132]. Speed, for example, is a feature of specially issued visas and visa-waivers, smart borders and streamlined bureaucratic procedures that are commonly used to expedite the movement of desirable border crossers (such as high-skilled professionals, investors and tourists).

Fast-tracked procedures are also deployed in order to block or eject undesirable flows, including those of asylum seekers. For example, FRONTEX, the European border agency, deploys 'rapid border intervention teams' in order to prevent the arrival of irregular migrants in European territory by, for instance, immobilising fishing vessels that would transport asylum seekers from North Africa. Between 2000 and 2015, asylum seekers in the UK were subject to a 'detained fast track' process allowing rapid assessments of asylum claims based on 'safe third country' generalisations (Cwerner, 2004; Gill, 2009; Griffiths, 2014). In 2014, Australia introduced a similarly fast-tracked procedure for asylum seekers arriving by sea and since 2012, has undertaken 'enhanced screening' of Sri Lankan and Vietnamese asylum seekers intercepted at sea (Kaldor Centre for International Refugee Law, 2015a, 2015b). Those deemed not to have valid protection claims under a rapid triage process have been promptly removed to states of 
origin or into the hands of sending-state authorities. Austrian laws introduced in 2016 also allow for fast-tracked refugee status determinations and removals under the terms of a state of emergency that would be triggered by a size-unspecified 'mass' arrival of asylum seekers (ECRE, 2016a). These techniques are designed to contain, deter, demoralise and/or immobilise would-be asylum seekers, whose unauthorised mobility is considered disorderly, undesirable and risky from a migration management perspective.

If high speed enables an expedited process of rejection and return, then slowness enables stalling techniques that prevent would-be migrants from reaching desired destinations or achieving status determinacy. The slowness or suspension of administration associated with migration results in sustained periods of stasis, indeterminacy or limbo that increasingly characterises the experience of many migrants, whether their mobility is framed in political or economic terms, as refugees or workers. Experiences of this kind are most obvious in the permanent temporariness of refugee camps which are home, over decades, to multiple generations. What the United Nations High Commissioner for Refugees (UNHCR) calls 'protracted refugee situations' covers only part of a more generalised phenomenon. Applying to situations in which 25,000 or more refugees of the same nationality have been displaced for five years or more in a given country of asylum, protracted refugee situations do not account for refugees or others who transit through more than one country for five years or more in search of a 'durable solution' or those whose unresolved exile is not amongst fellow nationals. Nevertheless, in 2016, some 11.6 million refugees (or two thirds of those under the UNHCR's mandate) were in protracted situations [UNHCR, (2017), p.22].

Sustained periods of indeterminacy result from numerous other administrative processes applying to irregular migrants. Among those with the most deleterious effects are prolonged and in some cases indefinite immigration detention that the UNHCR has recently described as more of a rule than an exception in numerous countries to which asylum seekers are drawn (UNHCR, 2014; see also Flynn, 2014; Griffiths, 2014; Elliot, 2016; Turnbull, 2016). Indeterminacy also ensues from forms of temporary protection for refugees and temporary leaves to stay for those in the asylum process. These temporary forms of status imply an ongoing potential for deportation and devastating human costs for those living with prolonged uncertainty (Leach and Mansouri, 2004; Hasselberg, 2016; Griffiths, 2014). The uncertainly is designed to deter asylum seekers from making claims to protection (ECRE, 2016b) and arguably, if claims are lodged, to make life so unbearable that claimants give up and go home.

Scholars in the Marxist tradition have drawn attention to slowness and border control insofar as they intersect with the demands of transnational labour markets. They argue that refugee camps and immigration detention serve the function of either containing surplus labour or releasing workers intermittently and under conditions that make workers more exploitable (De Genova, 2002; Tsianos and Karakayali, 2010). Others refer to 'benching' or holding certain kinds of migrant labour in reserve for 'just-in-time' delivery. Mezzadra and Neilson (2013), for example, note that certain kinds of skilled workers (such as IT professionals) are increasingly matched to the specific occupational demands of receiving states under temporary schemes. Rather than opening pathways to permanent residence, the visa conditions of such migrants are linked to market fluctuations for prolonged periods of time. Still, others argue that the prolonged experience of partial, temporary and reversible modes of inclusion is being extended to a greater variety of migrant workers, student-migrants and children of former migrants (Dauvergne and Marsden, 2011; Mares, 2016; Robertson, 2013). While such scholars 
acknowledge considerable differences between immigration detention and the 'benching' and differential inclusion of labour migrants, they also emphasise their continuities: "both involve strategies of temporal delay that stratify movements into the national labor market and polity" [Mezzadra and Neilson, (2013), p.150].

In light of these more critical approaches to temporal techniques of border control, it is possible to see fast-tracked or suspended status determination procedures, protracted refugee situations, routine migrant detention and permanently-temporary migrant labour schemes as inter-related phenomena. It is also possible to understand these phenomena less in terms of the unintended consequences of an imperfect administrative system migration management - that is doing what it can, under considerable constraints, to provide 'durable solutions' for the world's displaced and employment for migrant workers and more in terms of an endemic feature of a global regime that advances certain geopolitical and economic interests at the temporal expense of (would-be) migrants. Accordingly, Jeffrey (2008, p.954) argues that "chronic waiting" is a social condition that increasingly characterises the subaltern experience (see also Bayart, 2007; Martin, 2011). Chronic waiting entails long-term exclusion from geographic and social mobility. It is institutionalised within the administrative apparatus of states, intergovernmental organisations and contracted firms and NGOs and evinces an enduring colonialism whereby those held in camps, in detention and in hiding, are marked by criminality and a lack of civilisation. In the following section, we outline how each of these aspects of chronic waiting pertains to refugees stuck in Indonesia.

Asim is from the Darfur region of Sudan. He arrived in Indonesia in March 2013. He tried to take a boat to Australia but was stopped by the Indonesian Navy. He was detained by immigration authorities for three months, during which time he registered with the UNHCR. He escaped detention and paid a bribe to police in order to get to Jakarta by ship. In August 2013, he tried to reach Australia by boat again, but was caught and detained in Tanjung Pinang for 15 months. On 15 April 2014, he received his refugee status, but was not released from detention until December 2014. He has lived in the Sidoarjo centre since then.

A.M: Can you describe a typical day?

A: I wake, do some walking, come back and make some breakfast. I start reading a book. I read for about 6 hours a day. I read and study to improve my English. ... But it's hard to find books in English. ... I divide my reading like this: at 12 o'clock I read for two-three hours and one-two hours in the evening. That is a typical day for me... I call my family on the first day of the month when I get my allowance. It costs 100,000 Rupiahs to call. They don't have internet, so it's expensive to call...

A.M: What is it like to wait?

A: I have a lot of people waiting for me. All my family is dependent on me for support. They are waiting till now. They ask you - still no news? I say, they need patience, something like that. Even if you start the [resettlement] process you need two-three years. You have to tell them, they need patience... The waiting here - is different from other place in the world. Your role as a human being, all stop. You eat, you sleep, something like that. ... It's very hard to say waiting. Different kinds of waiting. In Malaysia, in Egypt, in Jordon you wait for your [refugee status determination] process, but you work. If your family is sick at home or someone needs support, you can send money. When they call you here and say your father, your mother, your grandmother is sick, you can't even reply. I can't say I hope they get well, because I can't help them. You find yourself helpless. This is why I say it's a different kind of waiting. When you are not working, forget the economics, when you are working you are doing something, you depend on yourself. It's good for your health. It's really hard when you can't work. I'd rather work for my meal. 


\section{Asylum seekers and refugees stuck in Indonesia}

From the late 1990s, increasing numbers of people fleeing conflict and persecution in Central Asia, the Middle East and later from Africa passed through Indonesia en route to Australia in order to seek asylum. For the Indonesian Government, the presence of such people has long been a peripheral concern approached in a largely ad hoc manner, on account of the assumption that asylum seekers and refugees were in transit and en route to somewhere else (Missbach, 2015). There is no legal pathway for local integration within Indonesia. Whilst not always detained, asylum seekers and refugees within Indonesian territory are vulnerable to immigration detention in prison-like facilities, often at the whim of police and other officials. In 2000, a Regional Cooperation Arrangement between Australia, Indonesia and the IOM was initiated. Under the terms of this agreement, Australia funded the IOM to provide support, accommodation and basic services for irregular migrants with protection claims in Indonesia and Indonesia allowed the operation of a status determination procedure through the UNHCR. For asylum seekers found to be refugees, Australia provided the vast majority of resettlement places (UNHCR Indonesia, 2014).

In 2013, however, the Australian Government implemented a comprehensive deterrence strategy under the codename 'operation sovereign borders'. The strategy involved turning back to Indonesia any vessels carrying asylum seekers en route to Australian territory, a cut-off date (1 July 2014) after which any asylum seeker who registered with the UNHCR in Indonesia would not be eligible for resettlement in Australia and a reduced quota for resettlement places for refugees based in Indonesia who had registered prior to the cut-off date. With fewer options for onward movement of any kind, the numbers of asylum seekers and refugees within Indonesia (whilst still not large by international standards) began to grow. ${ }^{1}$ According to the Australian Government, the measures were specifically intended to increase the waiting period for resettlement, such that those seeking asylum within Indonesia and protection in Australia or elsewhere enjoyed no advantage over refugees who waited for resettlement in less proximate locations (Australian Government, 2014). Australia's annual refugee resettlement quota would in this way be shaped by a selective process at the government's discretion, rather than by regional pressures prompted by spontaneous arrivals of asylum seekers. At the same time, the government emphasised that it would continue to fund the IOM in order to provide care to those in Indonesia with protection claims (Australian Government, 2014). This arrangement allowed the Australian Government to maintain its commitment to the humanitarian exercise of comprehensive border security and migration management. Indeed, Australia justified its overall deterrence strategy in humanitarian terms. In an example of what Williams (2016) calls 'the safety/security nexus' within border enforcement, Australia claimed to be preventing the deaths of asylum seekers at sea by removing the incentive (the chance of protection) for taking the journey in the first place. The containment of asylum seekers in origin and transit states without access to protection is increasingly justified by states in this way.

At the end of March 2016, some 13,848 'persons of concern' were registered with the UNHCR in Indonesia and the average waiting time between registration as asylum seekers and first round interviews for status determination was between 18 and 24 months [UNHCR Indonesia, (2016), p.4]. The full determination process takes several months or years longer. Those found to be refugees then wait to be referred by the UNHCR to a country with an official resettlement program and, in turn, for that country 
to assess the application for resettlement and to conduct any security checks required. If the application is rejected, the process of referral begins again. As asylum seekers and refugees cannot work legally, they rely on private funds for living expenses unless they become eligible for assistance from the UNHCR or the IOM. Of those receiving assistance from the IOM (some 6,209 at the end of January 2016), 54\% had been in Indonesia for between one and two years, $26 \%$ for between two and three years and $11 \%$ for more than three years (IOM, 2016). Recent years have seen asylum seekers self-reporting to Indonesian authorities on account of destitution [IOM, 2015c, pp.2-3]. Overcrowded detention centres make beds within them a scarce resource and a source of income for enterprising detention centre authorities. Hence, anecdotally, asylum seekers sometimes bribe those authorities to facilitate their own detention (interview with asylum seekers, Makassar, 10 May 2015). In addition and perversely, the only way to become eligible for IOM supported accommodation outside the detention system is to be referred from within detention centres. Thus, for asylum seekers and refugees with limited private funds, detention has become a necessary, if not compulsory, part of the waiting game.

The documentation of abuse suffered by asylum seekers and refugees within Indonesian immigration detention centres has prompted calls for a more humanitarian approach (Taylor, 2009; HRW, 2013). In the face of claims by senior Indonesian officials that Indonesia does not have the capacity to accommodate irregular migrants "in conditions which are 'good, right, healthy and human rights dimensional"' [cited in Nethery et al., (2013), p.99], Australia has since 2007 funded the IOM under a special program to 'build capacity' amongst Indonesian officials administering immigration detention and to act as service providers of migrant care (Taylor, 2010). The provision of care in this context has corresponded with the rise of a specific field of expertise in alternatives to detention (Costello and Kaytaz, 2013; Bloomfield et al., 2015; Sampson et al., 2015). Developed within the NGO sector as a 'pragmatic' approach, the alternatives to detention model provides examples of best practices and minimum standards in accommodating irregular migrants in community settings using detention only as a last resort. The model advocates a shift from a security driven approach to 'case resolution' as the ultimate focus. Alternatives to detention are shown to be more effective (in terms of ensuring migrant compliance with status determination decisions), affordable (in terms of reducing the costs associated with detention) and humane (enabling state compliance with international law and human rights norms) [Sampson et al., (2015), pp.2-3]. In each of these respects, the model fits within a migration management framework and precisely because of its adaptability to prevailing governmental rationalities the approach has had far reaching impact within key institutional and governmental fora (Morris, 2016). Alternatives to detention have been integrated into a five-year global strategy of the UNHCR to move 'beyond detention', which has, in turn, been brought to bear on a National Action Plan for Indonesia in collaboration with relevant Indonesian Government authorities and local and international NGOs (UNHCR Indonesia, 2015).

In their account of care models adopted within immigration facilities for families in the UK, Tyler et al. (2014) show how the financial sustainability of firms, NGOs and charities contracted to provide services within those facilities begins to rest increasingly on a market for migrant care. Similarly, in the Indonesian context, the IOM's ability to sustain its expanding Indonesian field mission has been increasingly linked to the border policing objectives of Australia, the mission's major donor, including the provision of 
migrant care. The IOM's Indonesia mission describes itself as being "at the forefront in supporting the Indonesian Government's continuing efforts to promote alternatives to detention for refugees and smuggled migrants" [IOM, (2014), p.4]. This positioning is indicative of the organisation's efforts to combine its mandate from member states with a broader representation of itself as a humanitarian organisation. ${ }^{2}$ Newsletters of the IOM's Indonesian mission showpiece exemplary cases of alternatives to detention. The "metamorphosis" of Sekupang Refugee Shelter on the island of Batam "from a prison-like facility to one of an apartment complex" is presented as indicative of "current migration management directions in Indonesia" [IOM, (2014), p.1]. That this custom built centre, with its high-quality utilities, recreational areas, disability access and proximity to hospitals, schools and markets is a prototype for the IOM's preferred model was confirmed to us by the Deputy Head of Mission (interview, Jakarta, 29 April 2015). He explained, however, that Australian donors had become less inclined towards custom-built facilities, preferring to repurpose existing buildings on account of shorter time frames and the flexibility this allowed to respond to fluctuating demand. Given that this preference is also shared by Indonesian authorities, the IOM highlighted a different accommodation centre in Sidoarjo, on the southern outskirts of the city of Surabaya, East Java, as their most promising example of accommodation facilities that were humane, non-custodial and linked to local development projects. For our inquiry, the Sidoarjo centre thus represented the best vantage point from which to observe refugees' experience of waiting under optimal conditions. We were accompanied by the IOM in a visit to the centre in May 2015, and returned independently on three consecutive days in April 2016. Our direct observations are drawn from these visits.

The Sidoarjo centre consists of three apartment blocks surrounded by perimeter fencing of the kind that might border any new housing estate. The apartments are part of a large market complex that was originally built by the local government as a development project. The market was intended to operate as a distribution centre for local farmers while the apartments would provide an additional customer-base and affordable housing for locals working in the area. For various reasons, the scheme failed leaving most of the market stalls and apartments vacant. The IOM saw an opportunity to repurpose the complex and after pursuing renovations (improving wiring, plumbing and maintenance), rented two apartment buildings from the local government (interview with IOM Indonesia Regional Cooperative Agreement Programme Coordinator, Java Region, Surabaya, 6 May 2015). In January 2016, the centre housed 339 male refugees, which represented $5.5 \%$ of those under IOM care in Indonesia (IOM, 2016). While refugee residents are technically able to come and go from the centre as they please, they are also required to provide a fingerprint record of their presence twice a day. The third apartment building, visibly more depleted than the others, is occupied by Indonesian families. Part of the market continues to operate, selling fresh meat, fish, vegetables and groceries to refugee and local residents alike and another section operates as a charcoal delivery terminal, emitting a strong and unpleasant smell on the days that we visited. As refugee residents, Mushaf and Hussein, explain in the vignettes below, days are filled by reading, jogging laps around the market complex, playing volleyball on the bitumen outside the market, walking to the nearby mosque or sitting, drinking tea, in small kiosks that cater largely to refugee customers.

In the accommodation blocks themselves, each apartment is shared by two men. The apartment consists of a bedroom with two separable beds and a large window that opens to catch the fresh air, a small sitting room with a mounted TV, where one person could 
sleep for more privacy, a basic kitchen with gas hotplate, a sink, drinking water and a space to cook. A monthly cash allowance of Rp 1,250,000 (approximately US \$100) is provided by the IOM to each refugee; refugees cook for themselves and pay for their own internet access. Each apartment opens onto a quadrangle, which is open-roofed and a garden has been planted on the ground floor. On the days we visit, the centre is clean and the atmosphere is calm. Young men meet in different apartments and congregate in common spaces on each floor; others lie sleeping or sitting in their rooms. Many have access to smartphones and other devices. Basic English lessons are provided - sometimes by refugees themselves, sometimes by teachers contracted by the IOM. The IOM rents the local indoor futsal field regularly for residents' use and there are occasional trips to a local swimming pool. According to the IOM, a 'psycho-social' emphasis is maintained in the centre including educational and vocational opportunities; psychological assessments and referral are undertaken by staff from a local hospital and university and general medical treatment is also available - though one refugee told us that he was compelled to pay for diagnostic blood tests (interview with IOM Indonesia Regional Cooperative Agreement Programme Coordinator, Java Region, Surabaya, 6 May 2015). The centre provides employment for locals as security guards and operational staff and as providers of recreational services, bus and motorcycle transport and provides additional customers for the market.

It was clear that IOM staff had invested considerable time and energy into the establishment and maintenance of the Sidoarjo centre, attempting to provide the best possible accommodation under considerable constraints. They had worked across the varied and sometimes competing interests of the multiple parties involved (Australian Government funders, local and federal Indonesian Government agencies, local businesses and local residents), had put in place agreements with local hospitals and service providers and were aware of certain tensions that could undermine the project and/or jeopardise the safety of refugees. Amongst communities with their own developmental challenges, the perception that 'foreigners' were being provided with special treatment (manifest, for example, in the visibly different standards of renovation between the three apartment buildings in the Sidoarjo complex) was a concern noted by the IOM (Ibid), local government authorities elsewhere in Indonesia (interview, Head of Subdistrict in Tama Lanrea, Makassar, 11 May 2015) and senior figures within the Ministry of Foreign Affairs, responsible for security issues in relation to irregular migration (interview with Director, International Security and Disarmament, Indonesian Ministry of Foreign Affairs, Jakarta, 13 May 2015).

The accommodation centre was a long way from the squalid and prison-like conditions in immigration detention that refugees and asylum seekers had experienced prior to arrival and in this respect represented a genuine improvement. Yet, the Sidoarjo centre continues to confine its residents spatially and temporally. In spatial terms, residents remain stuck on the outskirts of Surabaya, despite the open nature of the centre. Without being able to work, there is little reason and little money to go beyond the immediate vicinity of the centre. In temporal terms, the prolonged experience of waiting and indeterminacy remains unchanged in the Sidoarjo centre. As Asim describes in the vignette above, the waiting extends to the expectations of family and loved ones at home, whose futures also depend on his stalled role as provider. The sense of indeterminacy is compounded by the fact that the waiting persists despite the acquisition of refugee status, which for many of those refugees with whom we spoke had been anticipated as a 
milestone after which their experience would improve. As Boush and Mushaf intimate, the anticipation of a positive refugee status decision at least afforded some hope; but being a refugee whose resettlement process is indefinitely deferred affords frustration and demotivation.

Boush is a man in his twenties, a high school teacher from the Darfur region of Sudan. He arrived in Indonesia in May 2013 and registered promptly with the UNHCR in Jakarta. He lived independently for three months in Bogor, an area outside of Jakarta where asylum seekers can find cheaper accommodation. He tried three times to be smuggled to Australia by boat. On his last attempt, he was caught by police and detained for 18 months in Bangil Immigration Detention Centre. He received his refugee status whilst in detention and was subsequently sent to the Sidoarjo centre. He has lived there for over a year. He has not yet been referred by the UNHCR to any resettlement country. Before arriving in Indonesia, Boush lived in the same refugee camp in Darfur where his family has lived since 2003.

A.M: How do you spend your time?

B: I imagine things, and I write about peace, about freedom; sometimes about love, sometimes about suffering life, sometimes about good advice. Everything I have written, I have in my notebook. I'm wishing to write my life story. But no good conditions. I try. I could not find a suitable time to do some writing. While I still not get my resettlement - this make a big issue, still waiting for it. Everyone is waiting and hoping for it. When I see myself in the [resettlement] process, it would make a good feeling, I would feel free; then I can express my inside, to do what I need to do. But not at the moment. It's been 3 years and nothing, still no update. There is nothing I can do here. This is the reason I cannot write.

Young men from Somalia, Sudan, Afghanistan and Myanmar living in the Sidoarjo centre explained to us that they had been in Indonesia between two and four years, with sustained periods in detention, despite having been declared refugees by the UNHCR. It was unclear to them why some of their compatriots were released from detention upon receipt of refugee status, while others remained in detention for several months afterwards. It was unclear to them why the UNHCR referred some of their cases to resettlement countries and not others, and on what basis resettlement countries accepted or refused their cases. Sudanese and Somalis were anxious to know why they witnessed so few of their compatriots being accepted for resettlement compared with other nationalities, suspecting the reasons had racist dimensions. ${ }^{3}$ Each of them sought rational explanations for what appeared to them as arbitrary decisions. Encountering the administrative process as opaque, random and inexplicable is a feature of the experience of seeking asylum and resettlement noted by other scholars. In the UK context for example, Griffiths (2012) shows how asylum seekers and refugees are worn down over time by what they perceive as a double standard in truth: while they themselves risk jeopardising claims for protection with any minor discrepancy in their stories, the administration of their claims is characterised by human error, inconsistency and lack of transparency.

In a long conversation inside their apartment, three Somali refugees in the Sidoarjo centre complained of boredom, endless waiting, their inability to get on with their lives, an uncertain future, or no future at all. "Will we wait here forever?" they asked; "Will we die here?" (Interview, Sidoarjo Centre, 6 May 2015). They had trouble putting thoughts of this kind out of their heads; it upset them to talk about it and they recognised depression in themselves and others. Three months prior, a refugee from the centre had hung himself (for press reportage, see Primadi, 2015). Another, they revealed, had cut himself with a knife and had been taken to hospital. The waiting, they contended, made 
people crazy. We spoke with an Afghan refugee who had just finished teaching an English lesson. He explained that he taught to keep sane, to give his days structure and to stop his mind from thinking about his situation. The waiting, he explained, the not-knowing and not-understanding was at the forefront of everyone's mind. He listened to psychological experts on YouTube who recommended staying positive and thinking about his future - a task that surely set him up to fail, given the endless deferral of a future for which he could plan.

Mushaf is a young man from Afghanistan. He has lived at the Sidoarjo centre for over a year and previously spent time in Bangil Immigration Detention where he first met Boush.

A.M: How do you spend your time?

M: I stay busy. It's important to keep busy. I go with people if they need to go to the hospital; we talk and write English in my room, I help others improve their English; I play futsal, volleyball. I write. I read, from internet. I keep busy with thinking that is useful. When it's not useful [later: when I think about what has happened, what is happening], it's no good.

[To Boush] Remember when we were in detention together [before receiving refugee status], we would write; we wrote articles about non-violence, about peace. Remember? But here, somehow you know, we get lazy here.

As these conversations reveal, waiting takes on new and more excruciating forms, as refugee status fails to result in pathways towards a future in which opportunities for work, education, self reliance and family reunion exist. While a degree of relative 'luxury' can be said to pertain to the Sidoarjo centre - both in the sense of its distance from the worst examples of containment in immigration detention and by comparison with local conditions - a degree of confinement also persists in the sense of remaining captive in time. Even if the accommodation provided were genuinely luxurious, the simultaneous deferral of a substantive future renders a luxurious space a space of confinement nonetheless.

Under these conditions, it is no surprise that accommodation centres for asylum seekers and refugees in Indonesia continue to be sites of protest and demonstration, as residents object to their ongoing spatial and temporal confinement. In October 2015 alone, amongst approximately 9,000 asylum seekers and refugees under IOM care ${ }^{4}$, there were four separate incidents of hunger strikes involving multiple residents in detention centres and alternative accommodation, leading in one of the latter cases to 21 hospitalisations [IOM, 2015c, pp.26-27]. It is also no surprise that some refugees will seek ways to bring their limbo to an end. Hence, some continue in their attempts to be smuggled by boat to Australia, despite Australia's policy of returning such boats to Indonesia. ${ }^{5}$ Some refugees and asylum seekers will also opt for the IOM to administer an 'assisted voluntary return' (AVR) to their countries of origin. As Taylor and Rafferty-Brown (2010) point out, it is difficult to have confidence that the choice to return to places from which refugees have fled is voluntary in any meaningful sense, given the lack of other realistic options to end their temporal and spatial confinement. Just like those who risk their lives to be smuggled out of Indonesia by boat or those involved in hunger strikes, asylum seekers and refugees who accept voluntary return are likely to be making a calculated judgment that to risk one's life is a better option than living in indefinite limbo.

From 2012 to 2016, the number of AVRs from Indonesia exceeded the number of refugees departing for resettlement (4,066 to 3,918 respectively). ${ }^{6}$ Given this comparison, 
it is difficult to avoid the conclusion that life in limbo is designed, from a migration management perspective, to promote AVR as a 'case resolution' on at least equal terms with permanent resettlement, despite the risks entailed for refugees returning to places from which they have fled for fear of persecution. 'Resolving' refugees' cases in this way allows states such as Australia that fund migrant care whilst refusing resettlement to perpetuate structural violence entailed in migration management behind a veneer of benevolence and humanitarian concern. To the extent that alternatives to detention are promoted as leading to undifferentiated 'case resolutions', the model is also implicated in outcomes that align with migration containment strategies rather than the substantive provision of refugee protection.

\section{Be patient! The politics of waiting}

Increased attention to the prolonged indeterminacy experienced by asylum seekers and refugees in Indonesia and other countries of first asylum has prompted some scholars to question both the accuracy and the efficacy of terms like limbo (Hightower, 2015; Rotter, 2016; Sampson et al., 2016). For these scholars, the term limbo implies a degree of passivity that does not account for the 'life projects' undertaken by asylum seekers and refugees in spite of precarity and deprivation, nor their capacity for agency and resistance. There is no doubt that many refugees and asylum seekers, in Indonesia and elsewhere, show remarkable resourcefulness in the face of indeterminacy - a point we return to shortly. It is also the case, as these scholars point out, that narratives of passivity can be instrumentalised to serve governmental agendas. However, narratives of agency are equally susceptible to instrumentalisation. One kind of narrative projects a one-dimensional account of boredom, inactivity and lives-on-hold, fuelling the depiction of asylum seekers and refugees as victims of their own individualised failings and precisely the kind of hopeless cases that should be deterred in the first place. Another kind of narrative, that emphasises accomplishments and resilience, risks deflecting attention from the architecture that creates indeterminacy by suggesting that any sense of limbo is overstated. If asylum seekers and refugees can achieve so much and carry out a normal, even exemplary life under conditions of apparent indeterminacy, then surely, the logic proceeds, the waiting cannot be that bad.

Scholars who reflect On Waiting (Gasparini 1995; Hage, 2009a), reminds us that waiting has both passive and active dimensions. Waiting is both an interregnum and future oriented; it would not make sense to wait at all without an active sense of anticipation with which to make sense of the frustrations of endurance. The crucial point, as Hage (2009a, p.2) insists, rests on the politics of waiting: "[t]here is a politics around who is to wait. There is a politics around what waiting entails. And there is a politics around how to wait and how to organise waiting into a social system". He adds: "[t]here is a political economy of waiting, not least because 'time is money' and waiting can be a waste of time" [Hage, (2009a), p.3]. This emphasis on the politics and economics of waiting yields insight into the ways in which waiting is organised in and through migration management. In Indonesia, the wait for status determination and refugee resettlement might be seen, on one hand, somewhat benignly as something unavoidable that can be endured in better or worse ways (actively/passively) and as something that states manage (in better and worse ways) when it happens to take place on their territory. However, in keeping with Hage (2009a), it is possible to discern a politics around who is 
compelled to wait: those hoping for resettlement, for example, versus those 'volunteering' to return to states of origin; or those judged to be most 'at risk' versus those assessed as risky. It is possible to discern a politics around how long a person must wait (as we show below, the extent of one's human capital affects selection for resettlement), where they must wait (Indonesia versus Australia; 'offshore' versus 'onshore' more generally) and how they must wait (in an orderly fashion, quietly making the most of their time).

Hussein is a 19-year-old man from Somalia. He fled Somalia in order to avoid being forcibly recruited by Al Shabaab. He arrived in Indonesia in 2012 at the age of 15 and registered with the UNHCR. He was caught by Indonesian authorities attempting to reach Australia by boat and detained, first in a police holding cell with 16 others for one month and then in immigration detention for 11 months. He received his refugee status whilst in detention, but it was three months later before he was released. He has lived at the Sidoarjo centre for three years.

A.M: How do you spend your days?

H: I wake up around seven. I watch YouTube. I feel like I'm wasting time, not studying, not working. Life has stages - a time to learn, a time to work, a time to marry. The most important for me is study.

A.M: You'd like to be in school or university?

H: Of course. I'm waiting, my life, should be studying. You are not going anywhere here. ...I cook for something to do; clean the room. A three-minute job takes 30 minutes, just for something to do. Once a week, you might buy vegetables, some small groceries each day. And then it's sitting, hanging around, listen to music, feeling bored. Sometimes we play volleyball, or exercise in the morning... five months ago, there was a suicide. Someone from Afghanistan hung himself. He was 19 years old. People ... in their head, go crazy here. ...I wait here for resettlement. What else can I do? You have to obey the rules. I don't know why Australia doesn't take African refugees? I don't know why.

What one can do while waiting is of course affected by whether or not one waits in detention or has a degree of freedom and whether or not one is permitted to work, study or engage in other meaningful activity. Even when such freedoms and restrictions are applied equally to all asylum seekers and refugees, some are better able than others to make the most of their time on account of socio-economic positioning. A good illustration of uneven opportunities in this respect can be seen in the story of the Cisarua Learning Centre. ${ }^{7}$ The Learning Centre was established in 2014, in an area south of Jakarta, where many Afghan families live in private accommodation and at various stages of the status determination process. The Learning Centre provides education for Afghan, Iranian and other children who would not otherwise be able to go to school in Indonesia. The founders of the school - four highly educated, English-speaking and professionally trained Afghan male refugees - explained to us how they had made contact with an Australian film-maker who had provided initial funding to rent the school building. Further connections were made with an Australian International School in Jakarta that donated teaching materials and to the New South Wales Teachers Federation in Australia that provided training for volunteer teachers drawn from the Afghan community (interview, Cisarua Learning Centre, 7 May 2015). The founders had been able to leverage their human capital in order to build relationships with donors, mentors, supporters and trainers, who helped to make the Learning Centre possible and successful. Whilst not detracting from the extraordinary efforts of the founders of Cisarua Learning 
Centre or from the positive impact of the centre amongst children and parents from diverse socio-economic backgrounds, the case also speaks to the uneven capacities of differently skilled and networked refugees and asylum seekers to make the most of their time and hence to a political economy that overlays their varied experiences of waiting. For Hussein, in the vignette above, whose education has stalled, who lacks the means to support himself independently, and whose frustration with the endless waiting affects his mental health and motivation, the opportunities to make the most of his time are a world apart from those associated with the Learning Centre.

On the day we visited the Learning Centre in May 2015, the school was bursting with activity and energy in overwhelming contrast to the dispirited atmosphere that characterised the Sidoarjo centre and the accommodation and private dwellings of refugees and asylum seekers we had visited elsewhere in Indonesia. For many young people unable to attend the Learning Centre or who were older than school age, time spent waiting in relative isolation substituted for years that would otherwise be spent in education. The lost opportunity for education and its dispiriting effects may well incorporate a compound effect in relation to time spent waiting for resettlement. For example, while criteria used by states to assess applications for resettlement referred by the UNHCR remain somewhat opaque, a statement by the former Australian Minister for Immigration, Kevin Andrews, gives a sense of the value attached to skills and positive attitudes in the decision-making process. Commenting on his intention to place greater emphasis on the "capacity of visa applicants to settle" in Australia when assessing applications for protection visas, amongst others, Andrews (2007, p.157) included "an applicant's adaptability and resourcefulness, their knowledge of Australia and their expectation about living in Australia, their attitude towards learning English and their English language skills" as relevant criteria. Given that several of these criteria rely on opportunities to pursue education and the motivation to do so, it is reasonable to assume that those whose opportunities are poorer face a longer and possibly indefinite wait for resettlement.

The Minister's comments were made in the context of a 2007 decision to cut the intake of resettled refugees from Africa as a proportion of Australia's annual resettlement quota. This decision was made against the backdrop of a series of violent incidents in Australia that involved (sometimes as victims) young men of Sudanese and other African origin. In this context, Minister Andrews referred to Sudanese refugees as struggling to integrate, identifying in particular their youth, poor education and "long-time spent in refugee camps" as relevant "challenges" (cited in Caldwell, 2007; emphasis added). In this case, the Minister's words speak directly to the compound effects of waiting, especially in places considered to limit or deplete one's human capital. The longer the wait, the less suitable one becomes for resettlement schemes that can put an end to the waiting.

The Minister's comments, moreover, belie the notion of a queue for refugee resettlement. The idea of a queue has been a mainstay of Australian Governmental rhetoric justifying the refusal to accept asylum seekers who arrive on its territory spontaneously via Indonesia or elsewhere. From this perspective, an orderly system of resettlement responds first to those refugees who have been waiting longest and whose needs are considered greatest. In fact, as Andrews' comments attest, there is no such queue and selection for resettlement depends on a variety of factors, including regional priorities and preferences for certain nationalities (Karlsen, 2015), motivation and education. In addition, the selection of those 'most in need' currently takes the form of a 
'women at risk' category to which $12 \%$ of Australia's offshore resettlement quota is allocated (Karlsen, 2015). Given that the number of refugees far exceeds the number of available resettlement places, most would literally die waiting in any queue that were to exist. ${ }^{8}$ Hence, Fassin (2016) argues that "selective humanitarianism has replaced legal entitlement" when it comes to effective refugee protection. Those not selected are expected to wait even though waiting may well reduce their chances of resettlement.

Those who become frustrated, despairing or destructive whilst waiting, refusing to wait in an orderly fashion are increasingly subject to discipline. An extreme example comes from the Pacific state of Nauru, which hosts an Australian offshore detention centre. Against a backdrop of violence against refugees, waiting in the Nauruan community for resettlement, two refugees were charged and convicted in 2016 of the crime of attempting suicide under laws (since repealed) derived from the Australian state of Queensland's criminal code. Prosecutors argued for a custodial sentence in order to deter other refugees from using suicide "to get what they want" (cited in Walsh, 2016). This case resonates with a broader governmental narrative, in Australia and elsewhere, that depicts detained asylum seekers' acts of self-harm as disingenuous and manipulative, and as evidence of their cultural distance and unsuitability for resettlement in liberal states [for details see McNevin, (2011), pp.79-80]. Conlon and Gill (2013) document similar trends in immigration detention and accommodation facilities in the UK. They show how orientation literature, classes and manuals provided to detained asylum seekers are designed to inculcate attitudes and behaviours consistent with liberal democratic norms. Conlon and Gill (2011, p.250) argue, however, that the effect of these "technologies of government" is to "gag" asylum seekers in illiberal ways. While detainees learn that voice and empowerment are essential parts of liberal-democratic culture, they also learn that the wrong sort of voice exercised in the wrong sort of protest against their detention "may also be taken as confirmation of the unsuitability of certain individuals and groups of asylum seekers, thus as grounds for their exclusion, disenfranchisement, or expulsion from the state" [Conlon and Gill, (2016), p.256].

The trend appears again in the Indonesian context. In procedural guidelines, published by the IOM with support from Australian Customs and Border Protection, instructions are given to Indonesian authorities intercepting asylum seekers to inform them:

\begin{abstract}
...of the legal consequences for individuals who commit crimes in Indonesia, including damaging property, threatening and/or assaulting an officer and warn the migrants that the officer will ask the UNHCR to defer or refuse their registration requests and, in some cases advocate for the migrants to be deported to their country of origin. [IOM, (2012), p.20, emphasis added]
\end{abstract}

According to these instructions, asylum seekers should be warned that behaviour of the kind that has characterised riots and protests against abusive treatment inside immigration detention centres elsewhere (damage to property, for example) will result, not just in prosecution under Indonesian law, but also potentially in a refusal to assess protection claims and in prompt deportation. The instructions, which appear to promote interference in the timing and independence of the refugee status determination procedure should asylum seekers break the law, are intended to maintain orderly compliance amongst asylum seekers and refugees and to minimise disruption and dissent.

Against this backdrop of selective humanitarianism, disciplinary governance and chronic waiting, Ghassan Hage identifies a new form of governmentality whereby virtue 
is inculcated in the conduct of waiting patiently. This particular kind of virtue is inculcated in asylum seekers and refugees as well as in citizens of destination states. Common to both, argues Hage (2009b, pp.97-102) is a pervasive sense of what he calls "existential immobility" or "stuckedness". Stuckedness is the feeling of going nowhere, whether geographically, socially or economically, in a world in which others are perceived as being perpetually on the move, whether through crisis, luck or ingenuity but always in ways that takes advantage. Within states such as Australia, Hage (2009b, p.105) argues, "this sensibility has resulted in a perverse valorisation of waiting. One copes with existential immobility through "a celebration of heroic stasis" in which waiting is presented as something one should learn to do in an orderly and restrained fashion, irrespective of whether an end to the wait is in sight or exists at all. Accordingly, those who will not wait are demonised and vilified. Their impatience comes to reflect who they are, often in racialised and gendered ways, rather than the predicament they face in all its social and structural dimensions. Note, for example, in the Indonesian context, how 'women at risk', who frequently fit gendered and racialised stereotypes pertaining to innocent victims, are prioritised for resettlement, whilst single young men, fitting gendered and racialised stereotypes pertaining to sources of risk, must wait. According to Hage's account, those who wait too passively - waiting for 'handouts', perceived or real - will lose their place in the imaginary queue to others who make the most of their time and demonstrate the human capital required for resettlement. For Hage (2009b, p.105), the refusal of the asylum seeker, amongst other "third world-looking masses" to stay where they are and "wait out the crisis" in the right way plays out in terms of securitised civilisational divides between 'us' and 'them' and provides a circular rationale to deter, contain and immobilise.

In Indonesia, this governmentality of waiting operates in parallel with humanitarianisation. Humane material conditions ('luxury') provided for refugees fail to dislodge the temporal confinement (limbo or stuckedness) they experience and positions those who (still!) refuse to wait, or who will not wait in the right way, as all the more lacking in virtue. In this context, refusal to wait is interpreted as an unreasonable, culturally suspect, even criminal response (insofar as it may involve irregular transit), rather than a refusal to accept the reasonableness of the waiting game itself. To the extent that the irregular migrant is criminalised and culturally vilified in this way, the result is a circular justification for the security rationale underwriting migration management: border control responds to the increasing threat of 'illegal' migration and to the criminality and incivility of those who will not wait. To the extent that this justification sidesteps engagement with the politics of waiting, the result is the deferral of more fundamental questions about the legitimacy of forms of status and hierarchies of mobility enforced via migration management.

\section{Conclusions}

In this article, we have distinguished analytically between spatial and temporal dimensions of border control in order to show that humanitarianisation within one dimension - the space of refugee confinement - exists alongside ongoing deprivation in the other - the persistent time of waiting to which refugees are subject. We have argued, moreover, that improved conditions in refugee accommodation enables and legitimises ongoing deprivation in temporal terms. This relationship between space and time, 
'luxury' and limbo, is what we have called the humanitarianisation of waiting. We suggest that the humanitarianisation of waiting is an increasingly institutionalised feature of migration management. Attentiveness to migrant care within governmental, inter-governmental and non-governmental agencies designing and implementing migration management agendas runs in parallel with temporal techniques of border control and increasingly polarised experiences of the temporalities of mobility: access and speed on one hand, chronic waiting on the other.

In the Indonesian case, we have shown how an NGO-led and UN-sponsored model of alternatives to detention has resulted in improved material conditions for refugees awaiting resettlement. At the same time, refugees waiting under conditions of relative 'luxury' are positioned as unreasonable insofar as they expect or demand a more timely and transparent process of resettlement and an end to their limbo. Dozens of refugees made precisely this demand in February 2017 when they protested outside the offices of the UNHCR in Jakarta (Baqir Bayani, 2017). Precisely because alternatives to detention make time spent waiting appear to be more endurable, protests of this kind can appear to result from impatience, rather than injustice. The sense of endurability arising from this humanitarianisation of waiting ultimately serves to legitimise the deferral of resettlement and assisted returns to countries of origin. As features of migration management, deferrals and returns contain and immobilise would-be migrants in countries of origin and countries of first asylum. What and who is considered to be reasonable against this backdrop reflects the unequal politics of waiting alongside racialised and gendered assumptions that feed into circular logics of securitised border control.

Our argument should not be taken to suggest that the IOM or other agencies involved in the provision of care to asylum seekers, refugees and irregular migrants are somehow disingenuous in their efforts to deploy a more humane approach. Nor do we argue against alternatives to detention in principle. It would be foolish and unhelpful to contend that less restrictive, more comfortable and better-serviced forms of accommodation for refugees and asylum seekers do not represent an improvement on prison-like conditions in closed detention centres. Rather, we make a more subtle point: humanitarianism has been integrated into the fabric of migration management. This makes it impossible to disentangle the provision of care from the securitised interests of states or from a humanitarian market in which the IOM and NGOs are implicated as experts and service providers. The article thus cautions against interpretations of humanitarian border politics as either wholly detrimental or benign in their wider implications. Within the context of ongoing containment strategies, the impulse to alleviate their more obvious spatial hardships can obscure structures of violence that take temporal as well as spatial forms and contribute to their normalisation. ${ }^{9}$ Unless more humane alternatives (including alternatives to detention) are pursued in parallel with sustained critique of the structures of violence that condition detention in the first place, the best efforts to improve confinement may end up only preserving it.

\section{Acknowledgements}

Thanks to those waiting in Indonesia who took the time to share their experiences with us and to Boush, in particular, who was especially generous during our visits. Thanks also to Klaus Neumann, Sandy Gifford, Savitri Taylor, and Nic Maclellan, editors and reviewers for comments and suggestions on earlier drafts. 


\section{References}

Anderson, B. and Keith, M. (2014) Migration: The COMPAS Anthology, ESRC Centre on Migration, Policy and Society, Oxford.

Anderson, B., Sharma, N. and Wright, C. (2009) 'Editorial: why no borders?' Refuge, Vol. 26, No. 2, pp.5-18.

Andrews, K. (2007) 'Citizenship: committing to a way of life', The Sydney Papers, Vol. 19, No. 3, pp.152-159.

Australian Government (2014) Talking Points: Resettlement Cut-off Date for Refugees in Indonesia, Department of Immigration and Border Protection and Australian Customs and Border Protection, 19 November, Document released under Freedom of Information (on file with authors).

Bagelman, J. (2016) Sanctuary City: A Suspended State, Palgrave Macmillan, New York.

Baqir Bayani, M. (2017) Trapped in Limbo: Refugees Rally in Indonesia for Speedy UN resettlement, Asia Correspondent, 8 February [online] https://asiancorrespondent.com/ 2017/02/trapped-limbo-refugees-rally-indonesia-speedy-un-resettlement/\#vxh50IILSRvR Ka1k.97 (accessed 10 February 2017).

Barnett, M. (2011) Empire of Humanity: A History of Humanitarianism, Cornell University Press, Ithaca and London.

Bayart, J. (2007) Global Subjects: A Political Critique of Globalization, Polity Press, Cambridge.

Bloomfield, A. Tsourdi, E and Pelin, J. (2015) 'Alternatives to immigration and asylum detention in the EU: time for implementation', Odysseus Academic Network.

Bouchani, B. (2016) This is Manus Island. My Prison. My Torture. My Humiliation, The Guardian, Australia ed., 19 February [online] http://www.theguardian.com/commentisfree/2016/feb/19/ this-is-manus-island-my-prison-my-torture-my-humiliation (accessed 20 February 2016).

Brendese, P.J. (2013) 'Double crossed by the crossing: on the spacio-temporal borders of immigration', Contemporary Political Theory, Vol. 12, No. 3, pp.230-241.

Cabrera, L. (2013) 'Moral distance and global social justice: an archeology of borders', in Widdows, H and Smith, N.J. (Eds.): Global Social Justice, pp.42-57, Routledge, London and New York.

Caldwell, A. (2007) Australia Closes Door to African Refugees, ABC Online, 3 October [online] http://www.abc.net.au/worldtoday/content/2007/s2049830.html (accessed 10 July 2016).

Chimni, B.S. (2000) 'Globalization, humanitarianism and the erosion of refugee protection', Journal of Refugee Studies, Vol. 13, No. 3, pp.243-263.

Conlon, D. (2011) 'Waiting: feminist perspectives on spacings/timings of migrant (im)mobility', Gender, Place \& Culture, Vol. 18, No.3, pp.353-360.

Conlon, D. and Gill, N. (2013) 'Gagging orders: asylum seekers and paradoxes of freedom and protest in liberal society', Citizenship Studies, Vol. 17, No. 2, pp.241-259.

Costello, C. and Kaytaz, E. (2013) Building Empirical Research into Alternatives to Detention: Perception of Asylum Seekers and Refugees in Toronto and Geneva', United Nations High Commissioner for Refugees.

Cwerner, S.B. (2004) 'Faster, faster and faster: the time politics of asylum in the UK', Time and Society, Vol. 13, No. 1, pp.71-88.

Dauvergne, C. and Marsden, S. (2011) 'The ideology of temporary labour migration in the post-global era', Citizenship Studies, Vol. 18, No. 2, pp.224-242.

De Genova, N. (2002) 'Migrant 'illegality' and deportability in everyday life', Annual Review of Anthropology, Vol. 31, No. 1, pp.419-447.

Dutton, P. (2016) Boats Stopped - Threat Constant, Press statement, 18 March, Office of the Minister for Immigration and Border Protection, Australia [online] http://www.minister. border.gov.au/peterdutton/2016/Pages/boats-stopped-18032016.aspx (accessed 1 June). 
Elliot, A. (2016) 'Paused subjects: waiting for migration in North Africa', Time and Society, Vol. 25, No. 1, pp.102-116.

European Council on Refugees and Exiles (ECRE) (2016a) Austrian Parliament Approves Law Repudiating Right to Asylum, European Council on Refugees and Exiles [online] http://ecre. org/component/content/article/70-weekly-bulletin-articles/1468-austrian-parliament-approveslaw-repudiating-right-to-asylum.html (accessed 1 May 2016).

European Council on Refugees and Exiles (ECRE) (2016b) Sweden: Restrictive Changes to Asylum and Immigration Law, European Council on Refugees and Exiles [online] http://ecre.org/ component/content/article/70-weekly-bulletin-articles/1466-sweden-restrictive-changes-toasylum-and-immigration-law.html (accessed 1 May 2016).

Fassin, D. (2012) Humanitarian Reason: A Moral History of the Present, University of California Press, Berkley.

Fassin, D. (2016) From Right to Favor: The Refugee Question as Moral Crisis', The Nation, 5 April [online] http://www.thenation.com/article/from-right-to-favor/ (accessed 7 April 2016).

Flynn, M. (2014) 'There and back again: on the diffusion of immigration detention', Journal on Migration and Human Security, Vol. 2, No. 3, pp.165-197.

Gasparini, G. (1995) 'On waiting', Time \& Society, Vol. 4, No. 1, pp.29-45.

Geiger, M. and Pécoud, A. (Eds.) (2013) Disciplining the Transnational Mobility of People, Palgrave Macmillan, New York.

Gill, N. (2009) 'Presentational state power: temporal and spatial influences over asylum sector decisionmakers', Transactions of the Institute of British Geographers, Vol. 34, No. 2, pp.215-233.

Gill, N. (2016) Nothing Personal? Geographies of Governing and Activism in the British Asylum System, Wiley Blackwell, Oxford.

Griffiths, M. (2012) 'Vile liars and truth distorters': truth, trust and the asylum system', Anthropology Today, Vol. 28, No. 5, pp.8-12.

Griffiths, M. (2014) 'Out of time: the temporal uncertainties of refused asylum seekers and immigration detainees', Journal of Ethnic and Migration Studies, Vol. 40, No. 12, pp.1991-2009.

Hage, G. (2009a) 'Introduction', in Hage, G. (Ed.): Waiting, pp.1-12, Melbourne University Press, Melbourne.

Hage, G. (2009b) 'Waiting out the crisis: on stuckedness and governmentality', in Hage, G. (Ed.): Waiting, pp.97-106, Melbourne University Press, Melbourne.

Harrell-Bond, B. (1999) 'The experience of refugees as recipients of aid', in Ager, A. (Ed.): Refugees: Perspectives on the Experience of Forced Migration, pp.136-168, Continuum, London and New York.

Hasselberg, I. (2016) Enduring Uncertainty: Deportation, Punishment and Everyday Life, Berghan, New York.

Hightower, B. (2015) 'Refugees, limbo and the Australian media', International Journal for the Semiotics of Law, Vol. 28, No. 2, pp.335-358.

Human Rights Watch (HRW) (2013) Barely surviving: Detention, Abuse and Neglect of Migrant Children in Indonesia, Human Rights Watch [online] https:/www.hrw.org/sites/default/files/ reports/indonesia0613webwcover.pdf (accessed June 2016).

International Organization for Migration (IOM) (2005) International Agenda for Migration Management, Geneva and Berne-Wabern, International Organisation for Migration and Federal Office for Migration.

International Organization for Migration (IOM) (2012) Operational Booklet for the Coordinated Handling of People Smuggling: Interceptions, Investigations and Prosecutions in Indonesia, Jakarta, Indonesia. 
International Organization for Migration (IOM) (2014) IOM Indonesia Newsletter, Indonesia [online] http://indonesia.iom.int/newsletter (accessed 1 February 2017).

International Organization for Migration (IOM) (2015a) Migrant Statistics under Indonesia Programme as per 31 January 2015, unpublished source on file with authors, Jakarta, Indonesia.

International Organization for Migration (IOM) (2015b) 'Monthy report September 2015', The Regional Cooperation Arrangements in Indonesia, unpublished source on file with authors, Jakarta, Indonesia.

International Organization for Migration (IOM) (2015c) 'Monthy report October 2015', The Regional Cooperation Arrangements in Indonesia, unpublished source on file with authors, Jakarta, Indonesia.

International Organization for Migration (IOM) (2016) Migrant Statistics under Indonesia Programme as per 31 January 2016, unpublished source on file with authors, Jakarta, Indonesia.

Jeffrey, C. (2008) 'Waiting', Environment and Planning D, Vol. 26, No. 6, pp.954-958.

Kaldor Centre for International Refugee Law (2015a) Factsheet: 'Fast-Tracking' Refugee Status Determination, Sydney.

Kaldor Centre for International Refugee Law (2015b) Factsheet: Maritime Interception and Screening of Asylum Seekers at Sea, Sydney.

Karlsen, E. (2015) Refugee Resettlement to Australia: What Are the Facts?, Parliamentary Library Research Paper, 3 February, Parliament of Australia, Canberra.

Kotef, H. (2015) Movement and the Ordering of Freedom: On Liberal Governances of Mobility, Duke University Press, Durham and London.

Leach, M. and Mansouri, F. (2004) Lives in Limbo: Voices of Refugees under Temporary Protection, University of New South Wales Press, Sydney.

Little, A. (2015) 'The complex temporality of borders: contingency and normativity', European Journal of Political Theory, Vol. 14, No. 4, pp.429-447.

Mares, P. (2016) Not Quite Australian: How Temporary Migration is Changing the Nation, Text Publishing, Melbourne.

Martin, C. (2011) 'Turbulent stillness: the political uncertainty and the undocumented migrant', in Bissell, D. and Fuller, G. (Eds.): Stillness in a Mobile World, pp192-208, Routledge, New York.

McNevin, A. (2011) Contesting Citizenship: Irregular Migrants and New Frontiers of the Political, Columbia University Press, New York.

Mezzadra, S. and Neilson, B. (2013) Border as Method or the Multiplication of Labor, Duke University Press, Durham and London.

Missbach, A. (2015) Troubled Transit: Asylum Seekers Stuck in Indonesia, ISEAS-Yusof Ishak Institute, Singapore.

Morris, J. (2016) 'Power, capital and immigration detention rights: making networked markets in global detention governance at UNHCR', Global Networks, DOI:10.1111/glob.12124.

Morris, J. (2017) 'In the market of morality: International human rights standards and the immigration detention 'improvement' complex', in Hiemstra, N. and Conlon, D. (Eds.): Intimate Economies of Immigration Detention, pp.51-69, Routledge, New York.

Nethery, A., Rafferty-Brown, B. and Taylor, S. (2013) Journal of Refugee Studies, Vol. 26, No. 1, pp.88-109.

Primadi, M. (2015) Pengungsi Afganistan Tewas Gantung Diri Di Rusun Puspa Agro', Pojokpitu, 10 February [online] http://pojokpitu.com/baca.php?idurut=932\&\&top=1\&\&ktg= Jatim\&\&keyrbk=Peristiwa\&\&keyjdl=gantung\%20diri (accessed 1 June 2016).

Robertson, S. (2013) Transnational Student-Migrants and the State: The Education-Migration Nexus, Palgrave Macmillan, Basingstoke. 
Rotter, R. (2016) 'Waiting in the asylum determination process: just an empty interlude?', Time and Society, Vol. 25, No. 1, pp.80-81.

Sampson, R., Chew, V., Mitchell, G. and Bowring, L. (2015) There are Alternatives: A Handbook for Preventing Unnecessary Immigration Detention', Revised ed., International Detention Coalition, Melbourne.

Sampson, R., Gifford, S.M. and Taylor, S. (2016) 'The myth of transit: the making of a life by asylum seekers and refugees in Indonesia', Journal of Ethnic and Migration Studies, Vol. 42, No. 7, pp.1135-1152.

Squire, V. (2015) Post/Humanitarian Border Politics between Mexico and the US, Palgrave Macmillan, Basingstoke.

Taylor, J. (2009) Behind Australian doors: Examining the conditions of detention of asylum seekers in Indonesia [online] http://www.safecom.org.au/pdfs/behind-australian-doors-examining-theconditions.pdf (accessed 20 June 2016).

Taylor, S. (2010) 'Australian funded care and maintenance of asylum seekers in Indonesia and Papua New Guinea: all care but no responsibility?', UNSW Law Journal, Vol. 33, No. 2, pp.337-359.

Taylor, S. and Rafferty-Brown, B. (2010) 'Waiting for life to begin: the plight of asylum seekers caught by Australia's Indonesian solution', International Journal of Refugee Law, Vol. 22, No. 4, pp.558-592.

Ticktin, M. (2011) Casualties of Care: Immigration and the Politics of Humanitarianism in France, University of California Press, Berkeley.

Tsianos, V. and Karakayali, S. (2010) 'Transnational migration and the emergence of the European border regime: an ethnographic analysis', European Journal of Social Theory, Vol. 13, No. 3, pp.373-387.

Turnbull, S. (2016) 'Stuck in the middle': waiting and uncertainty in immigration detention', Time and Society, Vol. 25, No. 1, pp.61-79.

Tyler, I., Gill, N., Conlon, D. and Oeppen, C. (2014) 'The business of child detention: charitable co-option, migrant advocacy and activist outrage', Race and Class, Vol. 56, No. 1, pp.3-21.

United Nations High Commissioner for Refugees (UNHCR) (2014) Beyond Detention: A Global Strategy to Support Governments to End the Detention of Asylum Seekers and Refugees, United Nations High Commissioner for Refugees, Geneva.

United Nations High Commissioner for Refugees (UNHCR) (2017) UNHCR Global Trends. Forced Displacement in 2016, United Nations High Commissioner for Refugees, Geneva.

United Nations High Commissioner for Refugees (UNHCR) Indonesia (2013) Monthly Statistical Report, 30 September, unpublished source on file with authors.

United Nations High Commissioner for Refugees (UNHCR) Indonesia (2014) Monthly Statistical Report, 31 December, unpublished source on file with authors.

United Nations High Commissioner for Refugees (UNHCR) Indonesia (2015) UNHCR Global Strategy: Beyond Detention 2014-2019, National Action Plan, Jakarta.

United Nations High Commissioner for Refugees (UNHCR) Indonesia (2016) Monthly Statistical Report, March, (on file with authors).

Walsh, M. (2016) Iranian Refugee Father Convicted of Attempted Suicide in Nauru Resettlement Facility, ABC Online, 15 April [online] http:/www.abc.net.au/news/2016-04-15/iraniannauru-refugee-convicted-of-attempted-suicide/7328236 (accessed 17 April 2016).

Walters, W. (2011) 'Foucault and frontiers: notes on the birth of the humanitarian border', in Bröckling, U. et al (Eds.): Governmentality: Current Issues and Future Challenges, pp.138-164, Routledge, New York.

Williams, J. (2016) 'The safety/security nexus and the humanitarianisation of border enforcement', The Geographical Journal, Vol. 182, No. 1, pp.27-37. 


\section{Notes}

1 At the commencement of Operation Sovereign Borders in September 2013, there were 10,057 asylum seekers and refugees in Indonesia (UNHCR Indonesia, 2013). By March 2016, the number had grown to 13,848 , the highest in Indonesia for 16 years [UNHCR Indonesia, (2016), p.4].

2 See for example the IOM's promotional video IOM's Humanitarian Policy for Action [online] https://www.youtube.com/watch?v=HrSpBPF3YFY (accessed 1 June 2016).

3 From data available to us, we were not able to verify whether Somalis and Sudanese were proportionally under-represented amongst refugees of all nationalities based in Indonesia and accepted for resettlement.

4 Available statistics are for September 2015 and December 2015, showing, respectively, 9154 and 8754 asylum seekers and refugees under IOM care [IOM, (2015b), p.1, (2015c), p.1].

5 Between late 2013 and March 2016, there were 25 such turn-backs returning some 698 passengers to Indonesia and other countries (Dutton, 2016).

6 Total numbers of AVRs from Indonesia in 2012, 2013, 2014, 2015 and 2016 were 606, 975, $568,1,331$ and 586 respectively; total numbers of departures for resettlement during the same years were 257, 900, 848, 627 and 1,286 respectively [IOM, (2015a), p.10, (2015c), p.10; Anwar, (2017), p.19].

7 See http://cisarualearning.com/\#intro.

8 In 2016, 189,300 resettlement places were provided against a global total of 22.5 million refugees [UNHCR, (2017), pp.2-3].

9 Here we paraphrase Kotef (2015, p.49), reflecting on the humanitarianisation of checkpoint infrastructure in the Palestinian context. 